\title{
A rapid and efficient method for the extraction and identification of menaquinones from Actinomycetes in wet biomass
}

\author{
Fuquan Xie ${ }^{1,2}$, Shengxiang Pei ${ }^{2}$, Xihuang Lin ${ }^{3}$, Yun Tian ${ }^{1}$ and Gaiyun Zhang ${ }^{2^{*}}$
}

\begin{abstract}
Background: Menaquinones are constituents of prokaryote cell membranes where they play important functions during electron transport. Menaquinone profiles are strongly recommended for species classification when proposing a new Actinomycetes taxon. Presently, the most widely used methods to determine menaquinones are based on freeze-dried cells. Taxonomic research in our lab has revealed that menaquinone concentrations are low for some species of the genus Microbacterium, leading to difficulties in identifying menaquinones.

Results: Menaquinones extracted using the novel lysozyme-chloroform-methanol (LCM) method were comparable in quality to those obtained using the Collins method, the most widely used method. All tested strains extracted via the LCM method showed higher concentrations of menaquinones than those extracted via the Collins method. For some Microbacterium strains, the LCM method exhibited higher sensitivity than the Collins method, and more trace menaquinones were detected with the LCM method than the Collins method. In addition, LCM method is faster than the Collins method because it uses wet cells.
\end{abstract}

Conclusion: The LCM method is a simple, rapid and efficient technique for the extraction and identification of menaquinones from Actinomycetes.

Keywords: Actinomycetes, Menaquinone analysis, Menaquinone identification, Menaquinone extraction

\section{Background}

Menaquinones (MKs), also known as vitamin $\mathrm{K}_{2}$, are a large group of fat-soluble compounds composed of a common 2-methyl-1,4-naphthoquinone skeleton with a side chain of different numbers of isoprene units, which are referred to as MK-n (1-15) (Fig. 1) [1]. Since the 1970s, methods for chemotaxonomic characterization of MKs have been used to determine prokaryotic taxonomy $[2,3]$. MK extraction and determination methods for

\footnotetext{
* Correspondence: zhgyun@tio.org.cn

${ }^{2}$ Key Laboratory of Marine Biogenetic Resources, Third Institute of Oceanography, Ministry of Natural Resources, Xiamen 361005, Fujian, PR China

Full list of author information is available at the end of the article
}

Actinomycetes were described by Collins et al. in a paper that currently has more than 2000 citations [4-8]. In additional, a respiratory lipoquinone extraction method was reported in 2011 [9], while a screening method for MKproducing strains was reported in 2020 [10]. All of these MK extraction methods use freeze-dried cells. As the most widely used method, we applied the Collins et al. (1977) methodology to test the MKs from Actinomycetes strains in our lab. However, some strains within the genus Microbacterium show low or non-visible MK bands on a silica gel plate under ultraviolet (UV) radiation. The respiratory quinones from Microcella putealis $\mathrm{CV}-2^{\mathrm{T}}, \mathrm{CV}-40$ and AC-30 have also been detected at low concentrations

(c) The Author(s). 2021 Open Access This article is licensed under a Creative Commons Attribution 4.0 International License, which permits use, sharing, adaptation, distribution and reproduction in any medium or format, as long as you give appropriate credit to the original author(s) and the source, provide a link to the Creative Commons licence, and indicate if changes were made. The images or other third party material in this article are included in the article's Creative Commons licence, unless indicated otherwise in a credit line to the material. If material is not included in the article's Creative Commons licence and your intended use is not permitted by statutory regulation or exceeds the permitted use, you will need to obtain permission directly from the copyright holder. To view a copy of this licence, visit http://creativecommons.org/licenses/by/4.0/ The Creative Commons Public Domain Dedication waiver (http://creativecommons.org/publicdomain/zero/1.0/) applies to the data made available in this article, unless otherwise stated in a credit line to the data. 


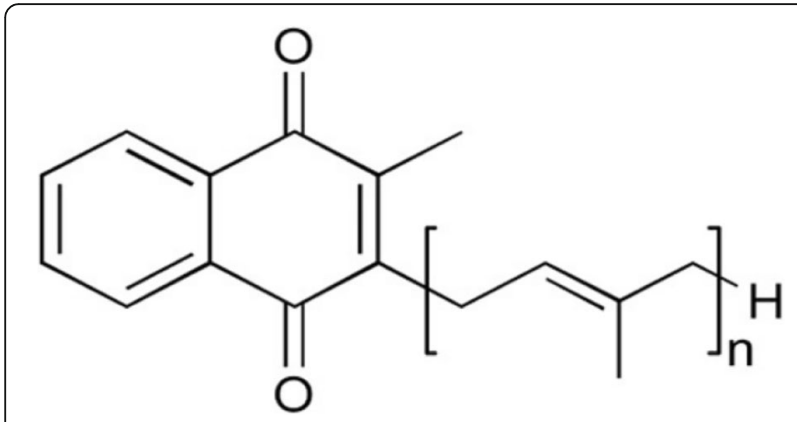

Fig. 1 Structure of menaquinones. $n=1-15$

when using $300 \mathrm{mg}$ of freeze-dried cells [11]. Low concentrations of MKs lead to difficulties in identifying MKs. In 2005, a water-soluble MK-7 extraction method for Bacillus subtilis natto was reported that demonstrated an increased MK-7 concentration using lysozyme [12]. In 2019, the effect of pretreatment methods for disrupting Bacillus subtilis natto cells was reported. Higher yields of MK-7 were obtained with chemical pretreatment methods (including the use of methanol, ethanol, n-propanol and 2propanol) than enzyme, freezing and heating or ultrasound treatments [13]. In this study, chemical methods using methanol, ethanol and ethyl acetate were initially used to disrupt wet cells of some Microbacterium strains before MK extraction. However, non-visible MK bands were found. Fortunately, higher yields of MKs were obtained by disrupting wet cells with lysozyme than those obtained using the Collins et al. (1977) methodology. Here, an improved, simple, rapid (1-day) and highresolution MK analysis method is reported for Actinomycetes.

\section{Results}

\section{Extraction of menaquinones}

The cells used for MK extraction were divided equally into two parts. For the lysozyme-chloroform-methanol (LCM) method proposed in this study, wet cells can be directly used for MK extraction. With this procedure, it takes about $3 \mathrm{~h}$ to acquire a crude extract of MKs. However, the Collins method requires hours or even an overnight period to acquire freeze-dried cells and then an overnight extraction is needed to obtain the crude extract of MKs. Therefore, the LCM method is faster than the Collins method.

In addition to the time saving feature, the LCM method obtains higher concentrations of MKs from $A c$ tinomycetes. In this study, the MK concentrations of the tested strains ranged from 0.063 to $0.921 \mathrm{mg} / \mathrm{g}$ dry cell weight (DCW) for the LCM method and 0.001 to 0.591 $\mathrm{mg} / \mathrm{g}$ DCW for the Collins method (Table 1). When the LCM method was used, the MK concentration from Saccharopolyspora coralli $\mathrm{E}^{2} \mathrm{~A}^{\mathrm{T}}$ was the lowest $(0.063 \mathrm{mg} / \mathrm{g}$ $\mathrm{DCW}$ ) among all the tested strains, but this concentration was higher than that of most strains extracted by the Collins method. Microbacterium ureisolvens CFH S00084 ${ }^{\mathrm{T}}$ showed the lowest MK concentration $(0.001 \pm$ $0.001 \mathrm{mg} / \mathrm{g}$ DCW) with an almost invisible MK band on thin layer chromatography (TLC) plates using the Collins method. However, when the LCM method was used, the MK concentration of strain CFH $500084^{\mathrm{T}}$ was 355 fold higher $(P<0.01)$ than that of the Collins method. In addition, the MK concentration of Brachybacterium squillarum JCM $16464^{\mathrm{T}}$ extracted via the LCM method was 33.2-fold higher $(P<0.01)$ than that of the Collins method. The MK concentrations of other strains

Table 1 Concentration of menaquinones (MKs) extracted by the LCM method and the Collins method

\begin{tabular}{|c|c|c|c|}
\hline \multirow[t]{2}{*}{ Strains } & \multicolumn{2}{|c|}{ Menaquinone concentration (mg/g DCW) } & \multirow{2}{*}{$\begin{array}{l}\text { Fold } \\
\text { change }\end{array}$} \\
\hline & $\begin{array}{l}\text { LCM method } \\
(n=3)\end{array}$ & $\begin{array}{l}\text { Collins method } \\
(n=3)\end{array}$ & \\
\hline Brachybacterium squillarum JCM $16464^{\top}$ & $0.664 \pm 0.040$ & $0.020 \pm 0.003$ & 33.2 \\
\hline Brevibacterium linens JCM $1327^{\top}$ & $0.110 \pm 0.011$ & $0.027 \pm 0.002$ & 4.1 \\
\hline Chryseoglobus frigidaquae JCM $14730^{\top}$ & $0.151 \pm 0.009$ & $0.041 \pm 0.007$ & 3.7 \\
\hline Georgenia subflava $\mathrm{Y}^{\top} 2^{\top}$ & $0.921 \pm 0.084$ & $0.054 \pm 0.007$ & 17.1 \\
\hline Janibacter melonis JCM $16063^{\top}$ & $0.715 \pm 0.079$ & $0.591 \pm 0.041$ & 1.2 \\
\hline Microbacterium yannicii JCM $18959^{\top}$ & $0.201 \pm 0.014$ & $0.041 \pm 0.005$ & 4.9 \\
\hline Microbacterium ginsengiterrae JCM $15516^{\top}$ & $0.322 \pm 0.035$ & $0.021 \pm 0.002$ & 15.3 \\
\hline Microbacterium ureisolvens CFH S00084 ${ }^{\top}$ & $0.355 \pm 0.022$ & $0.001 \pm 0.001$ & 355.0 \\
\hline Microbacterium hibisci CCTCC AB 2016180' & $0.081 \pm 0.031$ & $0.046 \pm 0.003$ & 1.8 \\
\hline Nesterenkonia halobia JCM $15475^{\top}$ & $0.100 \pm 0.010$ & $0.009 \pm 0.001$ & 11.1 \\
\hline Saccharopolyspora coralli E2A $\mathrm{A}^{\top}$ & $0.063 \pm 0.006$ & $0.012 \pm 0.001$ & 5.3 \\
\hline Yonghaparkia alkaliphile JCM $15138^{\top}$ & $0.087 \pm 0.001$ & $0.022 \pm 0.002$ & 4.0 \\
\hline Streptomyces indicus MCCC $1 \mathrm{~A}_{03308^{\top}}$ & $0.214 \pm 0.007$ & $0.163 \pm 0.006$ & 1.3 \\
\hline
\end{tabular}


extracted by the LCM method were 1.2-17.1-fold higher $(P<0.01)$ than those extracted by the Collins method. As an example, Fig. 2 shows MKs extracted from strain Microbacterium yannicii JCM $18959^{\mathrm{T}}$ using both methods and then detected by ultra-performance liquid chromatography (UPLC). Other strains are shown in Supplementary Figures 1 to 11 (Additional file 1). In general, for the same cell biomass, the MK concentration obtained by the LCM method was higher than that obtained by the Collins method.

\section{Identification of menaquinones}

As is well known, the UPLC system is faster and more sensitive than the high-performance liquid chromatography (HPLC) system. Thus, the UPLC system was used first for MK identification. The MK-9 standard and MKs extracted from strains O2 (MK-5 to MK-8), A18JL200 (MK-10 to MK-13) and NY27 (MK-13 to MK-15) were mixed as controls for method establishment. MK-5 to MK-15 were observed using the UPLC system at retention times of 1.10, 1.42, 2.16, 2.93, 3.51, 4.84, 6.70, 9.32, $12.98,18.14$ and $25.39 \mathrm{~min}$, respectively (Fig. 3A). Because UPLC equipment may not be available in every laboratory, HPLC was also used for MK separation in this study. MK- 5 to MK-15 were separated by the HPLC system with retention times of $5.27,6.49,8.68,10.88,12.36$, $15.71,20.20,26.12,33.98,44.46$ and $58.48 \mathrm{~min}$, respectively (Fig. 3C). In this study, both the HPLC and UPLC systems separated MK-5 to MK-15 well, with no significant difference between the two systems in their ability to separate these MKs. A larger sample volume $(10 \mu \mathrm{L})$ may be used to acquire a better signal for the HPLC system. The absorption spectrum of each MK exhibited two peaks: 247.5 and $269.5 \mathrm{~nm}$ for the UPLC system (Fig. 3B) and 248.3 and $269.6 \mathrm{~nm}$ for the HPLC system (Fig. 3D). The molecular mass of the MKs detected by mass spectrometer (MS), as shown by the mass spectra (Fig. 4), most accurately matched the ion fragment of $[\mathrm{M}+\mathrm{Na}]^{+}$(Table 2). According to the spectral absorption peak and molecular mass, we could confirm each of the MKs. Unsaturated MKs were observed for most of the strains in this study. Hydrogenated MKs of MK-5 $(\mathrm{H} 2)$, MK-7 (H2) and MK-8 (H2) were observed in strain O2; MK-9 (H2, H4) was observed in strain E2 $\mathrm{A}^{\mathrm{T}}$; and MK-9 (H4, H6, H8) was observed in strain MCCC $1 \mathrm{~A} 03308^{\mathrm{T}}$. MK-9 (H4), MK-9 (H6) and MK-9 (H8) from Streptomyces indicus MCCC $1 \mathrm{~A} 03308^{\mathrm{T}}$ extracted via the LCM method separated well using the UPLC system,

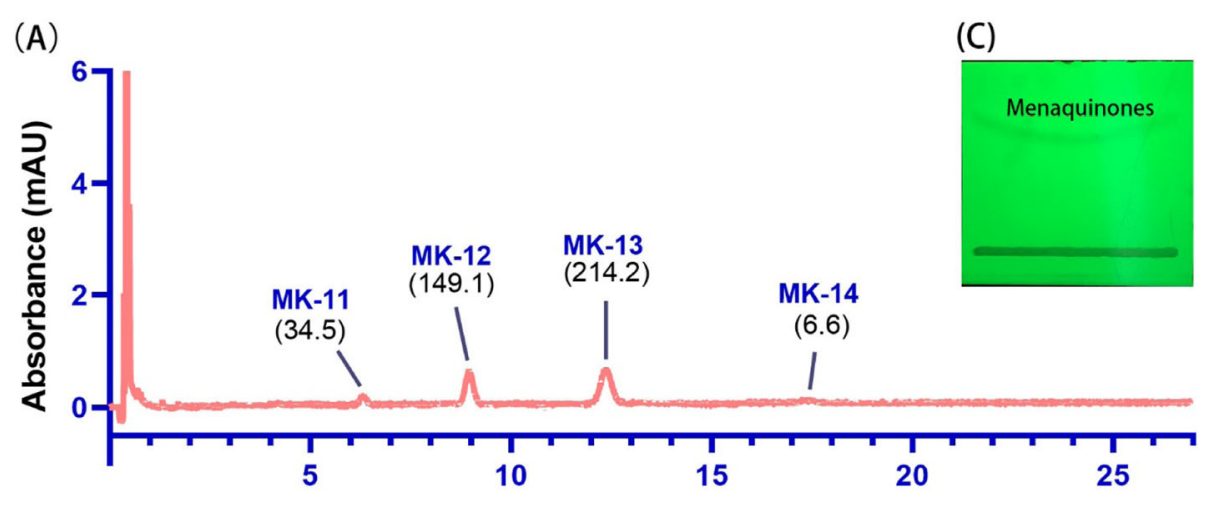

(B)

(D)

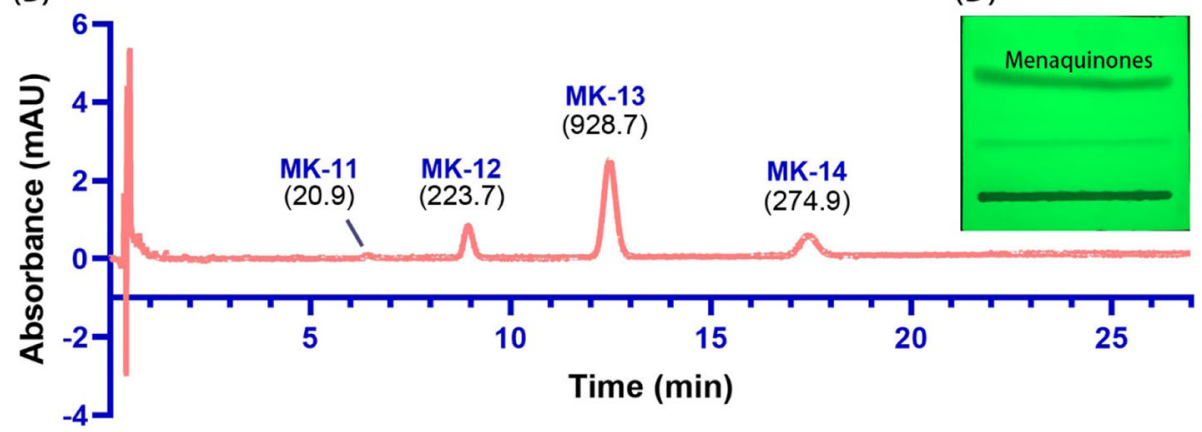

Fig. 2 TLC and UPLC-UV analysis of menaquinones (MKs) from Microbacterium yannicii JCM $18959^{\top}$ obtained using different MK extraction methods. A UPLC-UV analysis of MKs (absorbance at $270 \mathrm{~nm}$ ) extracted via the Collins method; B UPLC-UV analysis of MKs extracted via the LCM method. C and D: TLC of MKs (exposure to UV radiation at $254 \mathrm{~nm}$ ) extracted via the Collins method and LCM method, respectively. Strain M. yannicii JCM $18959^{\top}$ was chosen as a representative because the fold change of the MK concentration represents the median number of all tested strains. The peak area is shown in parentheses 


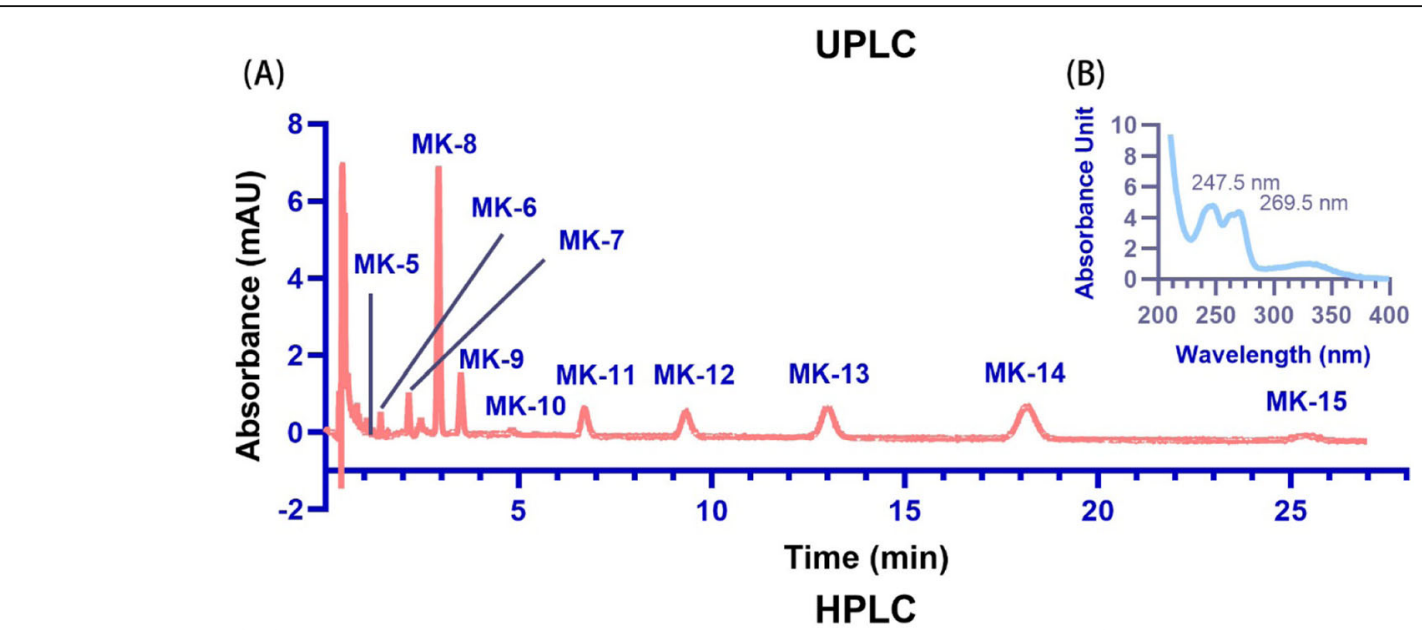

(C)

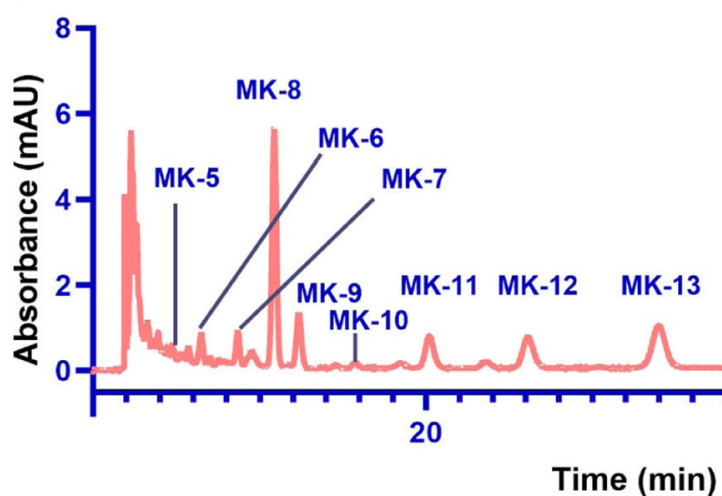

(D)

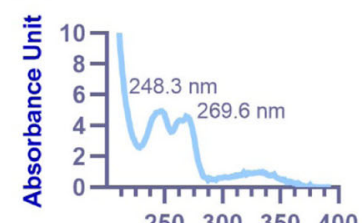

$\begin{array}{llll}250 & 300 & 350 & 400\end{array}$

MK-14

Wavelength (nm)

MK-15

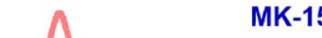

60

Fig. 3 UPLC and HPLC-UV analysis of extracted menaquinones (MK-5 to MK-15). A and C Representative UPLC and HPLC analyses, respectively, of the MK analogs as measured at an absorbance wavelength of $270 \mathrm{~nm}$. MK-5 to MK-8 were extracted from strain O2; MK-10 to MK-12 were extracted from strain A18JL200; and MK-13 to MK-15 were extracted from strain NY27. MK-9 was used as the MK standard. The absorption spectra of the MK-9 standard and other MKs show the same absorption peaks at 247.5 and $269.5 \mathrm{~nm}$ for UPLC (B), and 248.3 and $269.6 \mathrm{~nm}$ for HPLC (D)

showing retention times of $3.54,3.97$ and $4.52 \mathrm{~min}$, respectively (Fig. 5). Hydrogenated MKs also separated well using the HPLC system.

MKs of the tested strains using the LCM and Collins methods are shown in Table 3. The corresponding UPLC-UV data for these strains are shown in Supplementary Figures1 to 11 (Additional file 1). The main MKs of all the strains detected using both methods were primarily the same as reported (Table 3). The MK composition of the tested strains extracted with both the LCM and Collins methods were the same except for $M$.

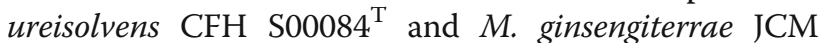
$15516^{\mathrm{T}}$. Specifically, MK-12 and MK-13 were the observed MKs from strains CFH $5000084^{\mathrm{T}}$ and JCM $15516^{\mathrm{T}}$ using the Collins method; however, along with MK-12 and MK-13, MK-11 and MK-14 were also detected with significant peaks in these two strains when using the LCM method (Additional file 1: Supplementary Figure 6 and 7).

\section{Discussion}

To validate the LCM method, the popular MK extraction protocol described by Collins et al. (1977) was used as a control to test the reliability of our MK extraction method from wet cells. During exploratory development of the LCM method, chloroform:methanol $(2: 1 \mathrm{v} / \mathrm{v})$ was first used to extract MKs directly from wet cells without a lysozyme pretreatment; however, no MKs were obtained from Microbacterium strains. Besides wet cells, freeze-dried cells can also be used for the LCM method, and there is no significant difference in MK concentrations between the wet cells and freeze-dried cells. However, the use of freeze-dried cells will extend the experimental time. For the lysozyme treatment conditions, the optimal concentration of lysozyme and incubation time are also different for different strains. Generally, most of the cells can be lysed with a final lysozyme concentration of $1 \mathrm{mg} / \mathrm{mL}$ and an incubation

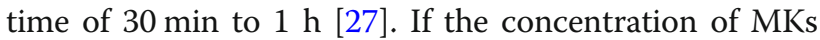



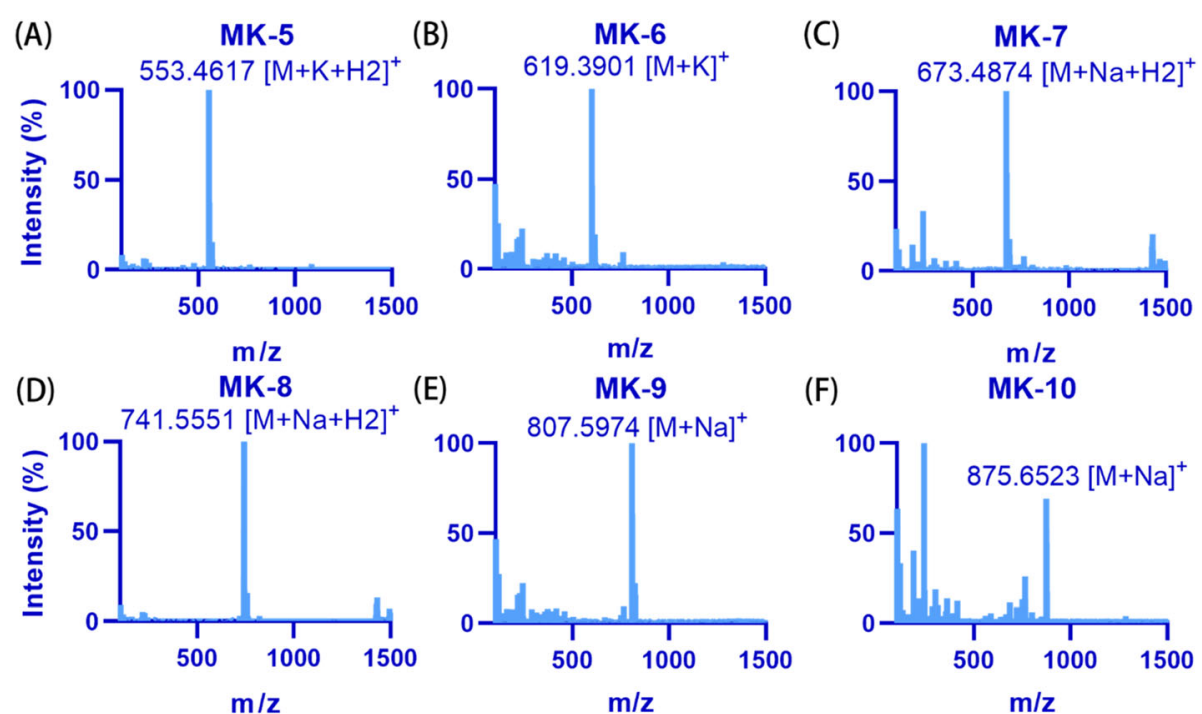

F)

MK-10
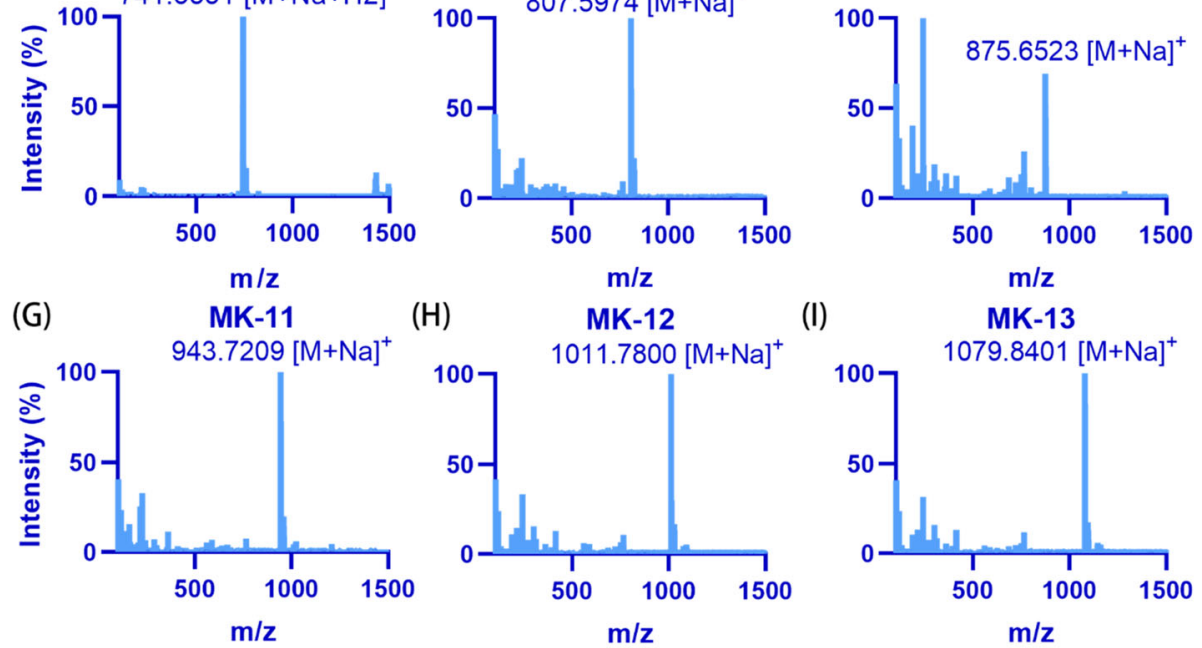

MK-12

(I)

MK-13
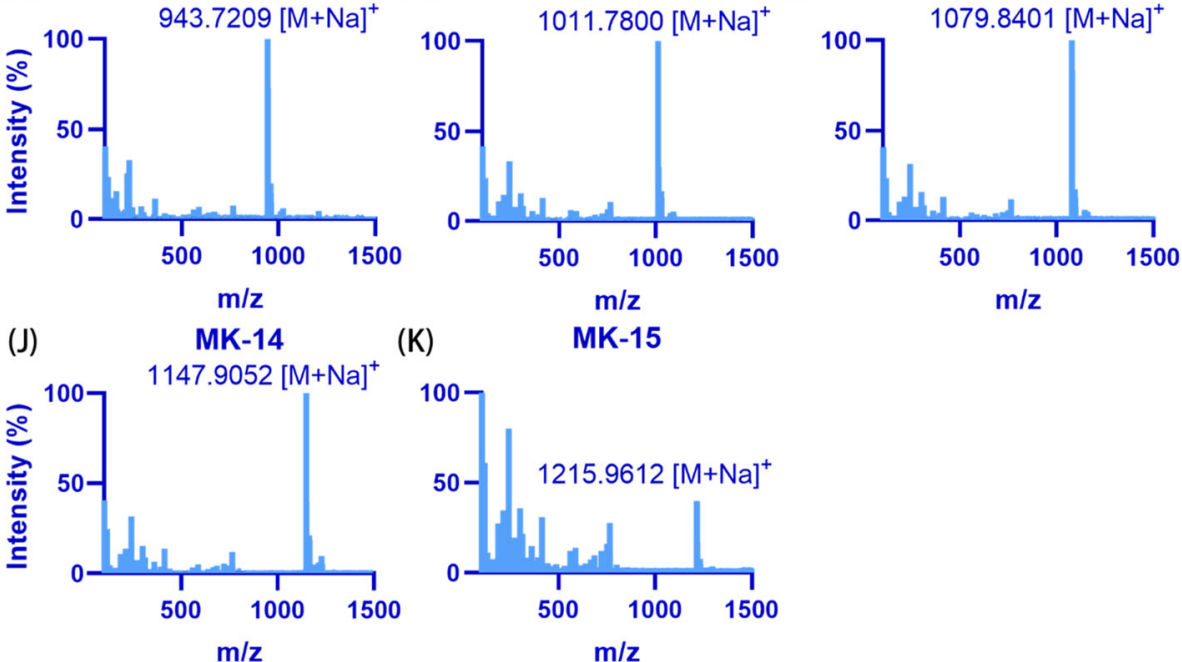

(K)

MK-15

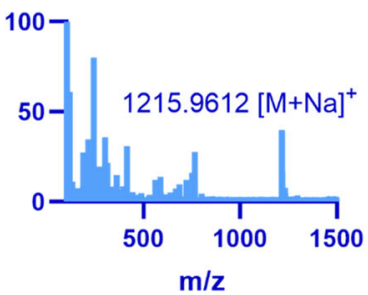

Fig. 4 Representative mass spectra of menaquinones (MKs). (A-K) Molecular weight from MK-5 to MK-15. In this system, ion fragments of MK-5 and MK-6 are shown as $[\mathrm{M}+\mathrm{K}+\mathrm{H} 2]^{+}$and $[\mathrm{M}+\mathrm{K}]^{+}$, respectively; $\mathrm{MK}-7$ and $\mathrm{MK}-8$ are shown as $[\mathrm{M}+\mathrm{Na}+\mathrm{H} 2]^{+}$; $\mathrm{MK}-9$ to $\mathrm{MK}-15$ are shown as $[\mathrm{M}+\mathrm{Na}]^{+}$

is low for LCM method, increasing the concentration of lysozyme and prolonging the treatment time will provide better results. Water in the lysozyme-treated cells should be removed using methanol or ethanol before the chloroform-methanol extraction step, otherwise the extraction efficiency will be reduced. TLC is an important purification and verification step during the MK extraction. Purified MKs were easily identified. However, if the MK concentration is low, the MK band $(\mathrm{Rf} \approx 0.7)$ on the TLC plate will be weak and not easily observed. As a result, minor MK components would not be detected by UPLC/MS or HPLC/MS. Accordingly, the MK intensity can be increased by concentrating the extract or increasing the injection volume. Better separation of MKs can be obtained using the ACQUITY UPLC ${ }^{\circ}$ HSS C18 column $(1.8 \mu \mathrm{m} 2.1 \times 100 \mathrm{~mm})$ with the UPLC system. The elution time is important for MK analysis. In order to avoid invalid elution, it is better to use an MK-15 standard as a reference for the analysis of UPLC or HPLC results, especially when the strain contains MK-12 to MK15. In addition, MKs are delicate components that are easily degraded. To prevent photo-oxidation, strong light should be avoided during the MK extraction process.

Overall, the results obtained using the LCM method were comparable in quality to those obtained using the standard freeze-dried approach. All tested strains extracted via the LCM method showed higher concentrations of MKs when compared with those extracted by the Collins method. Due to the high efficiency of MK extraction, the LCM method may serve as a general method for MK identification and screening of vitamin $\mathrm{K}_{2}$-producing Actinomycetes strains. 
Table 2 Reference molecular formulas and molecular weights for each menaquinone (MK) ion fragment

\begin{tabular}{|c|c|c|c|c|c|}
\hline MK & Molecular formula & {$[\mathrm{M}]^{+}$} & {$[\mathrm{M}+\mathrm{H}]^{+}$} & {$[\mathrm{M}+\mathrm{Na}]^{+}$} & {$[\mathrm{M}+\mathrm{K}]^{+}$} \\
\hline MK-1 & $\mathrm{C}_{16} \mathrm{H}_{16} \mathrm{O}_{2}$ & 240.115 & 241.1229 & 263.1048 & 279.0787 \\
\hline MK-2 & $\mathrm{C}_{21} \mathrm{H}_{24} \mathrm{O}_{2}$ & 308.1776 & 309.1855 & 331.1674 & 347.1413 \\
\hline MK-3 & $\mathrm{C}_{26} \mathrm{H}_{32} \mathrm{O}_{2}$ & 376.2402 & 377.2481 & 399.2300 & 415.2039 \\
\hline MK-4 & $\mathrm{C}_{31} \mathrm{H}_{40} \mathrm{O}_{2}$ & 444.3028 & 445.3107 & 467.2926 & 483.2665 \\
\hline MK-5 & $\mathrm{C}_{36} \mathrm{H}_{48} \mathrm{O}_{2}$ & 512.3654 & 513.3733 & 535.3552 & 551.3291 \\
\hline MK-6 & $\mathrm{C}_{41} \mathrm{H}_{56} \mathrm{O}_{2}$ & 580.4280 & 581.4359 & 603.4178 & 619.3917 \\
\hline MK-7 & $\mathrm{C}_{46} \mathrm{H}_{64} \mathrm{O}_{2}$ & 648.4906 & 649.4985 & 671.4804 & 687.4543 \\
\hline MK-8 & $\mathrm{C}_{51} \mathrm{H}_{72} \mathrm{O}_{2}$ & 716.5532 & 717.5611 & 739.5430 & 755.5169 \\
\hline MK-9 & $\mathrm{C}_{56} \mathrm{H}_{80} \mathrm{O}_{2}$ & 784.6158 & 785.6237 & 807.6056 & 823.5795 \\
\hline MK-10 & $\mathrm{C}_{61} \mathrm{H}_{88} \mathrm{O}_{2}$ & 852.6784 & 853.6863 & 875.6682 & 891.6421 \\
\hline MK-11 & $\mathrm{C}_{66} \mathrm{H}_{96} \mathrm{O}_{2}$ & 920.7410 & 921.7489 & 943.7308 & 959.7047 \\
\hline MK-12 & $\mathrm{C}_{71} \mathrm{H}_{104} \mathrm{O}_{2}$ & 988.8036 & 989.8115 & 1011.7934 & 1027.7673 \\
\hline MK-13 & $\mathrm{C}_{76} \mathrm{H}_{112} \mathrm{O}_{2}$ & 1056.8662 & 1057.8741 & 1079.856 & 1095.8299 \\
\hline MK-14 & $\mathrm{C}_{81} \mathrm{H}_{120} \mathrm{O}_{2}$ & 1124.9288 & 1125.9367 & 1147.9186 & 1163.8925 \\
\hline MK-15 & $\mathrm{C}_{86} \mathrm{H}_{128} \mathrm{O}_{2}$ & 1192.9914 & 1193.9993 & 1215.9812 & 1231.9551 \\
\hline
\end{tabular}

(A)

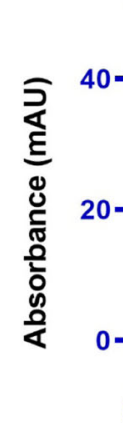

(C)

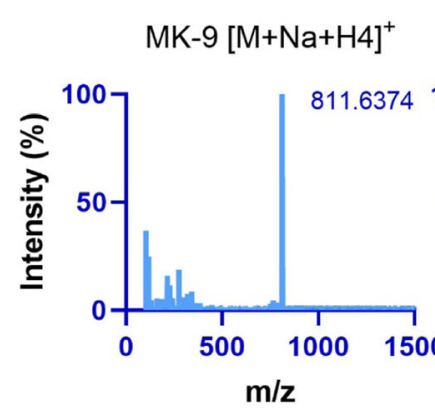

MK-9 (H6)

MK-9 (H4) / MK-9 (H8)
(B)

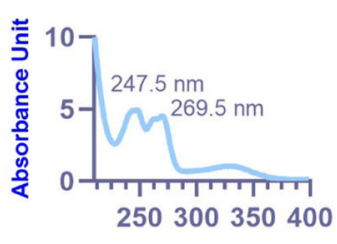

Wavelength $(\mathrm{nm})$

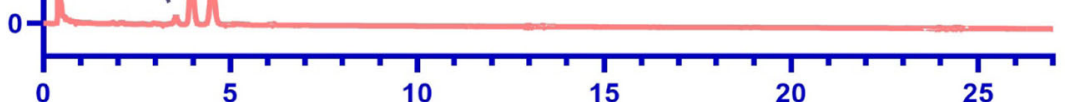

Time (min)

(D)

(E)

$\mathrm{MK}-9[\mathrm{M}+\mathrm{Na}+\mathrm{H} 6]^{+}$

MK-9 $[\mathrm{M}+\mathrm{Na}+\mathrm{H} 8]^{+}$
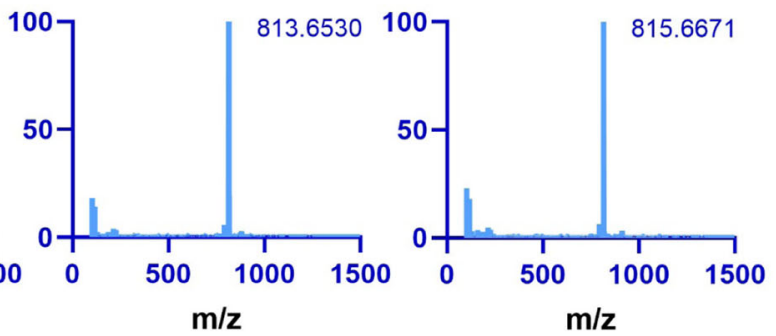

Fig. 5 Hydrogenated menaquinones (MKs) from Streptomyces indicus MCCC 1A03308 ${ }^{\top}$ separated using the UPLC-UV/MS system. A Representative peaks of MK-9 (H4), MK-9 (H6) and MK-9 (H8) from UPLC. B Absorption spectrum of MK-9. C-E Representative mass spectra of MK-9 (H4), MK-9 (H6) and MK-9 (H8), respectively 
Table 3 Menaquinone (MK) components from type strains as extracted by the lysozyme-chloroform-methanol (LCM) method and the Collins method, as well as those previously reported in the literature. Low-concentration MKs $(<10 \%)$ are shown in parentheses

\begin{tabular}{|c|c|c|c|}
\hline Strains & LCM method & Collins method & Reported menaquinones \\
\hline $\begin{array}{l}\text { Brachybacterium squillarum } \\
\text { JCM } 16464^{\top}\end{array}$ & (MK-6), MK-7, (MK-8) & (MK-6), MK-7, (MK-8) & $\begin{array}{l}\text { MK-7 } \\
{[14]}\end{array}$ \\
\hline $\begin{array}{l}\text { Brevibacterium linens } \\
\text { JCM } 1327^{\top}\end{array}$ & (MK-7), MK-8, (MK-9) & (MK-7), MK-8, (MK-9) & $\begin{array}{l}\text { MK-8 } \\
{[15]}\end{array}$ \\
\hline $\begin{array}{l}\text { Chryseoglobus frigidaquae } \\
\text { JCM } 14730^{\top}\end{array}$ & (MK-11), MK-12, MK-13, MK-14 & (MK-11), MK-12, MK-13, MK-14 & $\begin{array}{l}\text { MK-12, MK-13, MK-14 } \\
{[16]}\end{array}$ \\
\hline Georgenia subflava $\mathrm{Y} 32^{\top}$ & (MK-6), MK-7, (MK-8) & (MK-6), MK-7, (MK-8) & $\begin{array}{l}\text { MK-7, MK-8 } \\
{[17]}\end{array}$ \\
\hline $\begin{array}{l}\text { Janibacter melonis } \\
\text { JCM } 16063^{\top}\end{array}$ & $(\mathrm{MK}-7), \mathrm{MK}-8$ & $(M K-7), M K-8$ & $\begin{array}{l}\text { MK-8 } \\
{[18]}\end{array}$ \\
\hline $\begin{array}{l}\text { Microbacterium yannicii } \\
\text { JCM } 18959^{\top}\end{array}$ & (MK-11), MK-12, MK-13, MK-14 & (MK-11), MK-12, MK-13, (MK-14) & $\begin{array}{l}\text { MK-11, MK-12, MK-13 } \\
{[19]}\end{array}$ \\
\hline $\begin{array}{l}\text { Microbacterium ginsengiterrae } \\
\text { JCM } 15516^{\top}\end{array}$ & (MK-11), MK-12, MK-13, (MK-14) & MK-12, MK-13 & $\begin{array}{l}\text { MK-12, MK-13 } \\
{[20]}\end{array}$ \\
\hline $\begin{array}{l}\text { Microbacterium ureisolvens } \\
\text { CFH S00084 }\end{array}$ & (MK-11), MK-12, MK-13, (MK-14) & MK-12, MK-13 & $\begin{array}{l}\text { MK-11, MK-12, MK-13 } \\
{[21]}\end{array}$ \\
\hline $\begin{array}{l}\text { Microbacterium hibisci } \\
\text { CСТCC AB } 2016180^{\top}\end{array}$ & (MK-11), MK-12, MK-13, (MK-14) & (MK11), MK-12, MK-13, (MK-14) & $\begin{array}{l}\text { MK-12, MK-13 } \\
{[22]}\end{array}$ \\
\hline $\begin{array}{l}\text { Nesterenkonia halobia } \\
\text { JCM } 15475^{\top}\end{array}$ & MK-7, MK-8, MK-9 & MK-7, MK-8, MK-9 & $\begin{array}{l}\text { MK-8, MK-9 } \\
{[23]}\end{array}$ \\
\hline $\begin{array}{l}\text { Saccharopolyspora coralli } \\
E 2 A^{\top}\end{array}$ & MK-9 $(\mathrm{H} 2, \mathrm{H} 4)$ & MK-9 $(\mathrm{H} 2, \mathrm{H} 4)$ & $\begin{array}{l}\text { MK-9 } \\
{[24]}\end{array}$ \\
\hline $\begin{array}{l}\text { Yonghaparkia alkaliphile } \\
\text { JCM } 15138^{\top}\end{array}$ & MK-11, MK-12, MK-13 & MK-11, MK-12, MK-13 & $\begin{array}{l}\text { MK-12 } \\
{[25]}\end{array}$ \\
\hline $\begin{array}{l}\text { Streptomyces indicus } \\
\text { MCCC } 1 \mathrm{~A} 03308^{\top}\end{array}$ & MK-9 $(\mathrm{H} 4, \mathrm{H} 6, \mathrm{H} 8)$ & MK-9 (H4, H6, H8) & $\begin{array}{l}\text { MK-9 }(H 4, H 6, H 8) \\
{[26]}\end{array}$ \\
\hline
\end{tabular}

\section{Conclusion}

A simple, rapid and efficient method for identifying MKs from Actinomycetes in wet biomass was established. Compared with the Collins method, currently the most widely used method, MK extraction via the LCM method is more sensitive and time-saving.

\section{Methods}

\section{Chemicals and reagents}

All reagents and solvents used during the extraction were analytical grade. Strains were incubated in $2216 \mathrm{E}$ medium (pH 7.4 7.6), which was composed of $5.0 \mathrm{~g} / \mathrm{L}$ peptone, $1.0 \mathrm{~g} / \mathrm{L}$ yeast extract, $0.1 \mathrm{~g} / \mathrm{L} \mathrm{FeC}_{6} \mathrm{H}_{5} \mathrm{O}_{7}, 19.45$ $\mathrm{g} / \mathrm{L} \mathrm{NaCl}, 5.98 \mathrm{~g} / \mathrm{L} \quad \mathrm{MgCl}_{2}, 3.24 \mathrm{~g} / \mathrm{L} \quad \mathrm{Na}_{2} \mathrm{SO}_{4}, 1.8 \mathrm{~g} / \mathrm{L}$ $\mathrm{CaCl}_{2}, 0.55 \mathrm{~g} / \mathrm{L} \mathrm{KCl}, 0.16 \mathrm{~g} / \mathrm{L} \mathrm{Na}_{2} \mathrm{CO}_{3}, 0.08 \mathrm{~g} / \mathrm{L} \mathrm{KBr}$, $0.034 \mathrm{~g} / \mathrm{L} \quad \mathrm{SrCl}_{2}, 0.022 \mathrm{~g} / \mathrm{L} \quad \mathrm{H}_{3} \mathrm{BO}_{3}, 0.004 \mathrm{~g} / \mathrm{L} \mathrm{Na}_{2} \mathrm{SiO}_{3}$, $0.0024 \mathrm{~g} / \mathrm{L} \quad \mathrm{NaF}, \quad 0.0016 \mathrm{~g} / \mathrm{L} \quad \mathrm{NH}_{4} \mathrm{NO}_{3}$ and $0.008 \mathrm{~g} / \mathrm{L}$ $\mathrm{Na}_{2} \mathrm{HPO}_{3}$. Lysozyme (Solarbio Science \& Technology, Beijing, China) was used for cell wall digestion. Tris- $\mathrm{HCl}$ buffer $(10 \mathrm{mM}, \mathrm{pH} 7.4)$, chloroform-methanol $(2: 1 \mathrm{v} / \mathrm{v})$ and hexane-diethyl ether $(85: 15, \mathrm{v} / \mathrm{v})$ were used for MK extraction. These organic reagents were purchased from Xilong Scientific Co., Ltd., Guangzhou, China. The MK9 standard was purchased from GLPBIO, Montclair, CA, USA. Mass spectrometry-grade methanol (Sigma-
Aldrich, St. Louis, MO, USA) and isopropanol (Fisher Chemical, Thermo-Fisher Scientific Inc.) were used for high-performance liquid chromatography (HPLC), ultraperformance liquid chromatography (UPLC), and mass spectrometer (MS).

\section{Strains for menaquinone analysis}

Microbacterium yannicii JCM $18959^{\mathrm{T}}$, Microbacterium ginsengiterrae JCM $15516^{\mathrm{T}}$, Brachybacterium squillarum JCM $16464^{\mathrm{T}}$, Nesterenkonia halobia JCM $15475^{\mathrm{T}}$, Chryseoglobus frigidaquae JCM $14730^{\mathrm{T}}$, Brevibacterium linens JCM $1327^{\mathrm{T}}$, Yonghaparkia alkaliphila JCM $15138^{\mathrm{T}}$ and Janibacter melonis JCM $16063^{\mathrm{T}}$ were purchased from the Japan Collection of Microorganisms (JCM). Streptomyces indicus MCCC $1 \mathrm{~A} 03308^{\mathrm{T}}$ was purchased from the Marine Culture Collection of China (MCCC). Microbacterium hibisci CCTCC AB $2016180^{\mathrm{T}}$ was purchased from the China Center for Type Culture Collection (CCTCC).

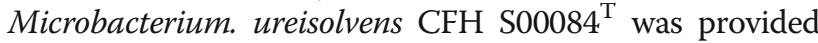
by Guo-Xing Nie, College of Fisheries, Henan Normal University, China. Saccharopolyspora coralli E2A ${ }^{\mathrm{T}}$, Georgenia subflava $\mathrm{Y}_{32}{ }^{\mathrm{T}}$, Microbacterium sp. NY27, Microbacterium sp. A18JL200 and Brevibacterium sp. O2 were isolated by our lab. 


\section{Equipment}

Test tubes and 1-L Erlenmeyer flasks were used for seed cultures and strain fermentation. Cell collection and MK extraction were performed with 50-mL centrifuge tubes (Sangon Biotech Co., Ltd., Shanghai, China) and an Eppendorf 5804R centrifuge (Eppendorf China Co., Ltd.). Lysozyme digestion was done in an electrothermostatic water bath (YiHeng technical Co., Ltd., Shanghai, China). Extracted MKs were dried using a rotary evaporator (Heidolph Instruments $\mathrm{GmbH} \& \mathrm{CO}$. KG). Thin-layer chromatography (TLC) was performed with $0.4-0.5 \mathrm{~mm}$ layers of silica-gel $\mathrm{HF}_{254}(10 \times 10 \mathrm{~cm})$ and a glass developing tank (Jiangyou Silica gel Development Co., Ltd., Yantai, China). MKs were observed under UV radiation with an UV analyzer (Chi Tang Industrial Co., Ltd., China). Organic solvent was filtered with 2-mL syringes (Kangyou Medical Equipment Co., Ltd., Jiangsu, China) and $0.22 \mu \mathrm{m} / 13 \mathrm{~mm}$ nylon syringe filters (Sangon Biotech Co., Ltd., Shanghai, China). Samples were injected into the HPLC system (Waters Alliance e2695) and the Waters ACQUITY UPLC ${ }^{\oplus}$ system from 2-mL amber screw top autosampler vials (ThermoFisher Scientific Inc.). The HPLC system was equipped with a 2998 PDA detector and a SunFire ${ }^{\mathrm{TM}}$ C18 column $(5 \mu \mathrm{m} 4.6 \times 150 \mathrm{~mm})$. The UPLC system was equipped with a $\mathrm{C} 18$ reversed-phase column $(1.7 \mu \mathrm{m} 2.1 \times 50 \mathrm{~mm}$, ACQUITY UPLC ${ }^{\oplus}$ BEH C18), a PDA e $\lambda$ detector and a high-resolution MS (Xevo G2 Q-TOF with electrospray ionization (ESI)).

\section{Strain cultivation and collection}

All strains used in this research were cultured on $2216 \mathrm{E}$ agar plates. A single colony was incubated in test tube containing $5 \mathrm{~mL}$ of $2216 \mathrm{E}$ medium at $28^{\circ} \mathrm{C}$ with $150 \mathrm{rpm}$ shaking until an optical density (OD at $600 \mathrm{~nm}$ ) of 0.6 was reached. Next, $2 \mathrm{~mL}$ of seed culture was added into 200 $\mathrm{mL}$ of $2216 \mathrm{E}$ medium in 1-L Erlenmeyer flasks and incubated for 3 to 4 days on a rotary shaker at $150 \mathrm{rpm}$ and $28^{\circ} \mathrm{C}$. Cells were divided into two equal parts for different MK extraction methods and then collected in 50-mL centrifugal tubes using an Eppendorf 5804R centrifuge at $6000 \times \mathrm{g}$ for $15 \mathrm{~min}$. Three independent replicates of strain cultivation and collection were carried out.

\section{Lysozyme-chloroform-methanol extraction method}

Since the thick cell wall of Actinomycetes can resist organic solvent extraction, an improved method named the lysozyme-chloroform-methanol (LCM) method was used to extract MKs. For this method, lysozyme was used to break the cell walls, followed by a chloroformmethanol $(2: 1 \mathrm{v} / \mathrm{v})$ extraction. After concentration using a rotary evaporator and purification via thin-layer chromatography (TLC), MKs were observed using a UV analyzer at $254 \mathrm{~nm}$ and eluted using isopropanol. Three replicates were carried out for the LCM method in this study.

Extraction steps were as follows:

1. Wet cellular mass (0.7-1.0 g) was acquired for each strain as described above.

2. Cells were washed twice with $20 \mathrm{~mL}$ of $10 \mathrm{mM}$ Tris- $\mathrm{HCl}$ buffer ( $\mathrm{pH}$ 7.4) to avoid media contamination, and then they were suspended in $50 \mathrm{~mL}$ of $10 \mathrm{mM}$ Tris- $\mathrm{HCl}$ buffer ( $\mathrm{pH}$ 7.4) with $50 \mathrm{mg}$ of lysozyme. The solution was mixed well by shanking for $1 \mathrm{~min}$ and incubated in a $37^{\circ} \mathrm{C}$ water bath for $1 \mathrm{~h}$ (with $1 \mathrm{~min}$ of shaking every $10 \mathrm{~min}$ ) to digest the cell wall. Next, the mixture was centrifuged for 15 min at $6000 \times$ g to collect the lysozyme-treated cells. (Note: the cell walls of some Actinomycetes are easy digested by lysozyme, forming a colloidal solution that is hard to centrifuge; thus, the next water removal step is important.)

3. Lysozyme-treated cells were washed with $5 \mathrm{~mL}$ of methanol (or ethanol) to remove water. The methanol (or ethanol) should be collected because it can dissolve some MKs. (Note: for easily-digested Actinomycetes, remove the water as much as possible after centrifugation and then add an equal volume of methanol (or ethanol) to the remaining solution. Shake several times and then centrifuge for $15 \mathrm{~min}$ at $6000 \times \mathrm{g}$. Cells can then be collected and washed with $5 \mathrm{~mL}$ of methanol (or ethanol). The top water-methanol solution should also be collected.)

4. Chloroform/methanol $(10 \mathrm{~mL}, 2: 1 \mathrm{v} / \mathrm{v})$ was added to the cells and then shaken for $1 \mathrm{~min}$ to extract MKs. The chloroform-methanol extraction was repeated three times. Approximately $30 \mathrm{~mL}$ of crude extract was acquired.

5. The methanol (or ethanol) and chloroformmethanol extracts were collected and dried using a rotary evaporator at $35^{\circ} \mathrm{C}$. The dry product was then dissolved with $500 \mu \mathrm{L}$ of chloroform-methanol $(2: 1 \mathrm{v} / \mathrm{v})$ three to four times.

6. The chloroform-methanol-dissolved crude extract was purified by TLC, which was performed using $0.4-0.5 \mathrm{~mm}$ layers of silica gel $\mathrm{HF}_{254}(10 \times 10 \mathrm{~cm})$ and a developing solvent consisting of hexane/diethyl ether $(85: 15, \mathrm{v} / \mathrm{v})$. MKs are routinely detected via TLC using brief irradiation with short-wave UV light $(254 \mathrm{~nm})$. In this system, the MKs migrate about $\mathrm{Rf} \approx 0.7$. The MK band was collected and eluted using $1.5 \mathrm{~mL}$ isopropanol.

7. Isopropanol-eluted MKs were filtered with $0.22 \mu \mathrm{m}$ nylon syringe filters into 2-mL amber screw top autosampler vials and then examined by UPLC-UV/ MS or HPLC-UV/MS 
Collins et al. (1977) method for menaquinone extraction Tubes containing wet cells were freeze-dried for $12 \mathrm{~h}$. Dried cells were mixed with $20 \mathrm{~mL}$ of chloroform/ methanol $(2: 1, v / v)$. The suspension was then continuously stirred overnight. The cells were then removed by filtration and the extract was dried by evaporation under reduced pressure at a low temperature $\left(35^{\circ} \mathrm{C}\right)$. Analytical TLC of quinones was performed using $0.4-0.5 \mathrm{~mm}$ layers of silica gel $\mathrm{HF}_{254}$ and a developing solvent consisting of hexane/diethyl ether $(85: 15, \mathrm{v} / \mathrm{v})$. Isopropanol was used to elute the quinones from the silica gel. Isopropanol-eluted $\mathrm{MKs}$ were filtered with $0.22 \mu \mathrm{m}$ nylon syringe filters into 2-mL amber screw top autosampler vials and then examined by UPLC-UV/MS or HPLC-UV/MS. Three replicates were carried out for the Collins method.

\section{Identification of menaquinones using the HPLC and UPLC-UV/MS systems}

For HPLC analysis, the mobile phase was a methanol/ isopropanol $(1: 1, \mathrm{v} / \mathrm{v})$ solution; the column temperature was set to $35^{\circ} \mathrm{C}$; the flow rate was $0.75 \mathrm{~mL} / \mathrm{min}$ for 65 min; and the injection volume was $10 \mu \mathrm{L}$. For UV analysis, the wavelength was set as $270 \mathrm{~nm}$ and the 3D spectrum range was from 210 to $400 \mathrm{~nm}$. For UPLC analysis, the mobile phase was methanol/isopropanol (3:1, $\mathrm{v} / \mathrm{v})$; the column temperature was set to $35^{\circ} \mathrm{C}$; the flow rate was $0.3 \mathrm{~mL} / \mathrm{min}$ for $27 \mathrm{~min}$; and the injection volume was $1 \mu \mathrm{L}$. For UV analysis, the wavelength was set as $270 \mathrm{~nm}$ and the 3D spectrum range was from 210 to $400 \mathrm{~nm}$. For MS analysis, electrospray ionization (ESI) was conducted in positive ion mode. A scan range of 100 to $1500 \mathrm{~m} / \mathrm{z}$ was used. The molecular weights of the MKs were then calculated using the $\mathrm{m} / \mathrm{z}$ ratios of their ion fragments (e.g., $[\mathrm{M}]^{+},[\mathrm{M}+\mathrm{H}]^{+}$and/or $[\mathrm{M}+\mathrm{Na}]^{+}$), and their accurate molecular formulae and chemical structures were subsequently confirmed. MK-9 was used as a reference.

\section{Quantification of menaquinones}

Three replicates were carried out to compare the LCM method and the Collins method. For each replicate, cells of each strain were divided into two equal parts, one for the LCM method and the other for the Collins method. Tubes containing wet cells for the Collins method were freeze-dried for $12 \mathrm{~h}$. The dry cell weight (DCW) was calculated as: $\mathrm{DCW}=$ the total weight of the centrifuge tube containing dry cells - weight of the empty centrifuge tube. The DCW used in the LCM method was based on that used for the Collins method. MK concentrations were measured via the UPLC system, using MK9 as the standard, as previously described [28]. The yield was expressed as mg menaquinones/g dry biomass. The data were analyzed for comparison using SPSS 19 software and values are reported as mean \pm standard deviation (SD) $(n=3)$. One-way analysis of variance (ANOVA) was used to test the significance of the two methods.

\section{Abbreviations}

MK: Menaquinone; LCM: Lysozyme-chloroform-methanol;; UV: Ultraviolet; DCW: Dry cell weight; TLC: Thin layer chromatography; UPLC: Ultraperformance liquid chromatography; HPLC: High-performance liquid chromatography; MS: Mass spectrometer; JCM: Japan Collection of Microorganisms; MCCC: Marine Culture Collection of China; CCTCC: China Center for Type Culture Collection; SD: Standard deviation; ANOVA: One-way analysis of variance.

\section{Supplementary Information}

The online version contains supplementary material available at https://doi. org/10.1186/s12866-021-02240-z.

\section{Additional file 1.}

\section{Acknowledgements}

Not Applicable.

\section{Authors' contributions}

Experiments were designed by Fuquan Xie, Gaiyun Zhang and Yun Tian, and carried out by Fuquan Xie and Shengxiang Pei. HPLC and UPLC-UV/MS methods for menaquinones were optimized by Fuquan Xie and Xihuang Lin. Data were analyzed by Fuquan Xie, Gaiyun Zhang and Yun Tian. The manuscript was written by Fuquan Xie, Gaiyun Zhang and Yun Tian. All authors read and approved the final manuscript.

\section{Funding}

This work was supported by the Scientific Research Foundation of the Third Institute of Oceanography, MNR, No. 2019011 and the China Ocean Mineral Resources R\&D Association (COMRA) Program, No. DY135-B2-01.

Availability of data and materials

All data generated or analyzed during this study are included in this published article [and its supplementary information files].

\section{Declarations}

Ethics approval and consent to participate

Not applicable.

Consent for publication

Not applicable.

Competing interests

The authors declare that they have no competing interests.

\section{Author details}

${ }^{1}$ Key Laboratory of the Ministry of Education for Coastal and Wetland Ecosystems, School of Life Sciences, Xiamen University, Xiamen 361102, Fujian, PR China. ${ }^{2}$ Key Laboratory of Marine Biogenetic Resources, Third Institute of Oceanography, Ministry of Natural Resources, Xiamen 361005, Fujian, PR China. ${ }^{3}$ Analysis and test center, Third Institute of Oceanography, Ministry of Natural Resources, Xiamen 361005, Fujian, PR China.

Received: 8 March 2021 Accepted: 23 May 2021

Published online: 09 June 2021

\section{References}

1. Mahdinia E, Demirci A, Berenjian A. Implementation of fed-batch strategies for vitamin $\mathrm{K}$ (menaquinone-7) production by Bacillus subtilis natto in biofilm reactors. Appl Microbiol Biotechnol. 2018;102(21):9147-57. https:// doi.org/10.1007/s00253-018-9340-7. 
2. Yamada Y, Inouye G, Tahara Y. Kond, Ocirc, Keiji. The menaquinone system in the classification of coryneform and nocardioform bacteria and related organisms. J Gen Appl Microbiol. 1976;22(4):203-14. https://doi.org/10.2323/ jgam.22.203.

3. Collins MD, Jonse D, Goodfellow M, Minnikin DE. Isoprenoid quinone composition as a guide to the classification of listeria, brochothrix erysipelothrix and caryophanon. Microbiology. 1979;111(2):453-7. https://doi. org/10.1099/00221287-111-2-453.

4. Collins MD, Pirouz T, Goodfellow M, Minnikin DE. Distribution of menaquinones in actinomycetes and corynebacteria. J Gen Microbiol. 1977; 100(2):221-30. https://doi.org/10.1099/00221287-100-2-221.

5. Tamaoka J. Analysis of bacterial menaquinone mixtures by reverse-phase high-performance liquid chromatography. Methods Enzymol. 1986;123:2516. https://doi.org/10.1016/s0076-6879(86)23028-1.

6. Collins MD, Goodfellow M, Minnikin DE, Alderson G. Menaquinone composition of mycolic acid-containing actinomycetes and some sporoactinomycetes. J Appl Bacteriol. 1985;58(1):77-86. https://doi.org/1 0.1111/j.1365-2672.1985.tb01431.x.

7. Collins MD, Faulkner M, Keddie RM. Menaquinone composition of some sporeforming actinomycetes. Syst Appl Microbiol. 1984;5(1):20-9. https://doi. org/10.1016/S0723-2020(84)80048-X.

8. Tamaoka J, Katayama-Fujimura Y, Kuraishi H. Analysis of bacterial menaquinone mixtures by high performance liquid chromatography. J Appl Bacteriol. 1983;54(1):31-6. https://doi.org/10.1111/j.1365-2672.1983.tb01297.x.

9. Da Costa MS, Albuquerque L, Nobre MF. Wait R. 9 - The Extraction and Identification of Respiratory Lipoquinones of Prokaryotes and Their Use in Taxonomy. In: Rainey F, Oren A, editors. Methods in Microbiology: Academic Press; 2011. p. 197-206.

10. Cao S, Du X, Li P, Yuan G, Chen S, Chen W, et al. A chemical screening method for menaquinone-producing strains based on HPLC-UV technology. J Microbiol Methods. 2020;172:105907. https://doi.org/10.1016/j.mimet.202 0.105907 .

11. Tiago I, Pires C, Mendes V, Morais PV, da Costa M, Verissimo A. Microcella putealis gen. Nov., sp. nov., a gram-positive alkaliphilic bacterium isolated from a nonsaline alkaline groundwater. Syst Appl Microbiol. 2005;28(6):47987. https://doi.org/10.1016/.jsyapm.2005.03.004

12. Yanagisawa $Y$, Sumi $H$. Natto bacillus contains a large amount of watersoluble vitamin K (menaquinone-7). J Food Biochem. 2005;29(3):267-77. https://doi.org/10.1111/j.1745-4514.2005.00016.x.

13. Fang $Z$, Wang $L$, Zhao $G$, Liu $H$, Wei $H$, Wang $H$, et al. A simple and efficient preparative procedure for menaquinone-7 from Bacillus subtilis (natto) using two-stage extraction followed by microporous resins. Process Biochem. 2019:83:183-8. https://doi.org/10.1016/j.procbio.2019.05.008.

14. Park S-K, Kim M-S, Jung M-J, Nam Y-D, Park E-J, Roh SW, et al. Brachybacterium squillarum sp. nov., isolated from salt-fermented seafood. Int J Syst Evol Microbiol. 2011;61(5):1118-22. https://doi.org/10.1099/ijs.0.022 517-0.

15. Collins MD, Kroppenstedt RM, Támaoka J, Komagata K, Kinoshita T. Structures of the tetrahydrogenated menaquinones from Actinomadura angiospora, Faenia rectivirgula, and Saccharothrix australiensis. Curr Microbiol. 1988:17(5):275-9. https://doi.org/10.1007/BF01571328.

16. Baik KS, Park SC, Kim HJ, Lee KH, Seong CN. Chryseoglobus frigidaquae gen Nov., sp. nov., a novel member of the family Microbacteriaceae. Int J Syst Evol Microbiol. 2010;60(Pt 6):1311-6. https://doi.org/10.1099/ijs.0.016212-0.

17. Wang S, Xu X, Wang L, Jiao K, Zhang G. Georgenia subflava sp. nov., isolated from a deep-sea sediment. Int J Syst Evol Microbiol. 2015;65(11):4146-50. https://doi.org/10.1099/ijsem.0.000553.

18. Yoon JH, Lee HB, Yeo SH, Choi JE. Janibacter melonis sp. nov., isolated from abnormally spoiled oriental melon in Korea. Int J Syst Evol Microbiol. 2004. 54(Pt 6):1975-80. https://doi.org/10.1099/ijs.0.63167-0.

19. Karojet $S$, Kunz $S$, van Dongen JT. Microbacterium yannicii sp. nov., isolated from Arabidopsis thaliana roots. Int J Syst Evol Microbiol. 2012;62(Pt 4):8226. https://doi.org/10.1099/ijs.0.026955-0.

20. Kim Y-J, Kim MK, Bui TPN, Kim H-B, Srinivasan S, Yang D-C. Microbacterium ginsengiterrae sp. nov., a $\beta$-glucosidase-producing bacterium isolated from soil of a ginseng field. Int J Syst Evol Microbiol. 2010;60(12):2808-12. https:// doi.org/10.1099/ijs.0.015784-0.

21. Cheng L-j, Ming H, Zhao Z-L, Ji W-L, Zhang L-Y, Li L-Y, et al. Microbacterium ureisolvens sp. nov., isolated from a Yellow River sample. Int J Syst Evol Microbiol. 2019:69(2):560-6. https://doi.org/10.1099/ijsem.0.003203.
22. Yan ZF, Lin P, Won KH, Yang JE, Li CT, Kook M, et al. Microbacterium hibisci sp. nov., isolated from rhizosphere of mugunghwa (Hibiscus syriacus L.). Int I Syst Evol Microbiol. 2017;67(9):3564-9. https://doi.org/10.1099/ijsem.0.002167.

23. Stackebrandt E, Koch C, Gvozdiak O, Schumann P. Taxonomic dissection of the genus Micrococcus: Kocuria gen. Nov., Nesterenkonia gen. Nov., Kytococcus gen. Nov., Dermacoccus gen. Nov., and Micrococcus Cohn 1872 gen. Emend. Int J Syst Bacteriol. 1995;45(4):682-92. https://doi.org/10.1099/ 00207713-45-4-682.

24. Zhou Y, Pei S, Xie F, Gu L, Zhang G. Saccharopolyspora coralli sp. nov. a novel actinobacterium isolated from the stony coral Porites. Int J Syst Evol Microbiol. 2020;70(5):3241-6. https://doi.org/10.1099/ijsem.0.004162.

25. Yoon JH, Kang SJ, Schumann P, Oh TK. Yonghaparkia alkaliphila gen. Nov., sp. nov., a novel member of the family Microbacteriaceae isolated from an alkaline soil. Int J Syst Evol Microbiol. 2006;56(Pt 10):2415-20. https://doi. org/10.1099/ijs.0.64258-0.

26. Luo Y, Xiao J, Wang Y, Xu J, Xie S, Xu J. Streptomyces indicus sp. nov., an actinomycete isolated from deep-sea sediment. Int J Syst Evol Microbiol. 2011;61(Pt 11):2712-6. https://doi.org/10.1099/ijs.0.029389-0.

27. Boström KH, Simu K, Hagström $\AA$, Riemann L. Optimization of DNA extraction for quantitative marine bacterioplankton community analysis. Limnol Oceanogr Methods. 2004;2(11):365-73. https://doi.org/10.4319/lom.2 004.2.365

28. Wei $H$, Zhao G, Liu H, Wang $H$, Ni W, Wang $P$, et al. A simple and efficient method for the extraction and separation of menaquinone homologs from wet biomass of Flavobacterium. Bioprocess Biosyst Eng. 2018;41(1):107-13. https://doi.org/10.1007/s00449-017-1851-6.

\section{Publisher's Note}

Springer Nature remains neutral with regard to jurisdictional claims in published maps and institutional affiliations.

Ready to submit your research? Choose BMC and benefit from:

- fast, convenient online submission

- thorough peer review by experienced researchers in your field

- rapid publication on acceptance

- support for research data, including large and complex data types

- gold Open Access which fosters wider collaboration and increased citations

- maximum visibility for your research: over $100 \mathrm{M}$ website views per year

At $\mathrm{BMC}$, research is always in progress.

Learn more biomedcentral.com/submissions 